\title{
Uma certa perspectiva da palavra na cena contemporânea
}

\author{
ANTONIO GUEDES
}

Prenant comme point de départ la réflexion d'Antonin Artaud sur le langage, j'essaierai de rendre évidente la rupture qu'il propose en ce qui concerne la structure narrative traditionnelle. Inversant l'ancienne conception de l'art comme copie du monde, nous partirons de l'hypothèse d'un langage dont la force expressive est tellement forte qu'elle dépasse la simple description des faits ou des idées. Considérant l'oeuvre comme une création autonome qui n'envoie à quoique ce soit en dehors d'elle-même, je chercherai une compréhension de la parole comme pouvoir d'instauration, comme geste artistique, comme action. Au théâtre contemporain, le langage exige que nous le comprenions non comme instrument de communication, mais comme force d'instauration. En refusant le débat sur les formes narratives, cet essai affirme que, au-delà du jeu entre forme et contenu, le théâtre se tourne exclusivement vers la réalisation d'une expérience entre la scène et le public. Cette question va être thématisée à partir de mes mises en scène de textes de Koltès, Beckett et, en particulier, de la structure narrative des oeuvres de Valère Novarina, afin de comprendre, dans la dramaturgie contemporaine, dans quelle mesure le sujet est vidé pour favoriser l'émergence du langage lui-même comme matière de construction et de l'homme et du monde.

THÉÂTRE / COMMUNICATION / LANGAGE / NOVARINA / ARTAUD

O século XX revolveu, de muitas maneiras diferentes, a concepção de linguagem construída como instrumento de comunicação desde o Renascimento. Entretanto, por considerar Artaud, dentre outros pensadores preocupados com a construção de uma outra perspectiva de linguagem, aquele com cuja obra dialogo sempre que possível, recorro a um trecho de uma carta escrita ao seu psiquiatra e que me serviu de mote para empreender esta narrativa sobre a palavra na cena contemporânea:

Je suis un ignorant. Je me suis cru longtemps sûr du sens des mots, je me suis cru aussi jusqu'à un certain point leur maître. Mais maintenant que je les ai quelque peu expérimentés, il m'échappe.

Pourquoi? 
Les mots valaient ce que je leur faisais dire, c'est-à-dire ce que je mettais dedans. Mais je n'ai jamais pu savoir au juste jusqu'à quel point j'avais raison. (Artaud, 1977: 64)

A questão da linguagem está presente em toda a obra de Artaud; ela está no centro das suas preocupações desde o princípio. Para ele, era necessário abandonar a «sujeição do teatro em relação ao texto e reencontrar a noção de uma espécie de linguagem única a meio caminho entre o gesto e o pensamento» (Artaud, 1984: 94). Essa questão não exigia uma mera mudança de forma narrativa, ou seja, não era apenas contra a tradição dramática que ele se voltava, mas contra a hegemonia do texto sobre a experiência. A transformação que ele exigia passava inevitavelmente por uma outra concepção da linguagem que, em vez de ter uma função descritiva, comunicadora de conteúdos, seria responsável por instaurar uma relação cujo sentido só poderia brotar da experiência, do jogo. A importância do teatro, para Artaud, não estava no relato de fábulas, mas na possibilidade de promover a experiência de uma dimensão outra da vida, um lugar que está fora do cotidiano.

Ele despertou para essa questão a partir da sua incapacidade de utilizar a linguagem articulada de forma natural, não pensada. É que seu pensamento se recusava a ser descrito e, por isso, não encontrava a palavra adequada para expressá-lo. Mas ele nunca deixou, não sem sofrimento, de buscar a forma mais precisa para expressar o que se passava em sua cabeça e, na angústia do esforço, ao longo de sua obra - seja nas cartas, nas poesias, nas peças ou nos manifestos -, Artaud revelava a palavra como um corpo estranho. Seu discurso tinha o aspecto da fala de um estrangeiro que se esforça por se expressar em uma língua que conhece mal. Nessas circunstâncias, costumamos ouvir as palavras que dizemos; pensamos na construção da frase.

Quando utilizamos a linguagem como um instrumento de comunicação de conteúdos, temos como foco não as palavras, mas o que queremos dizer. Entretanto, a narrativa de Artaud parece desenvolver-se sem a naturalidade que faz a linguagem passar despercebida. A palavra para Artaud é, principalmente, forma sonora, intensidade, ritmo, volume; a palavra, antes de querer dizer, afirma sua presença enquanto possibilidade de dizer. Ela se abre para a percepção daquele que a ouve; ela assume sua antiga (mas sempre presente) força poética. A palavra, nessa perspectiva, é trágica, porque não é aquilo que nos possibilita o domínio do sentido, mas, justamente, a perda; não é o meio de apreendermos 


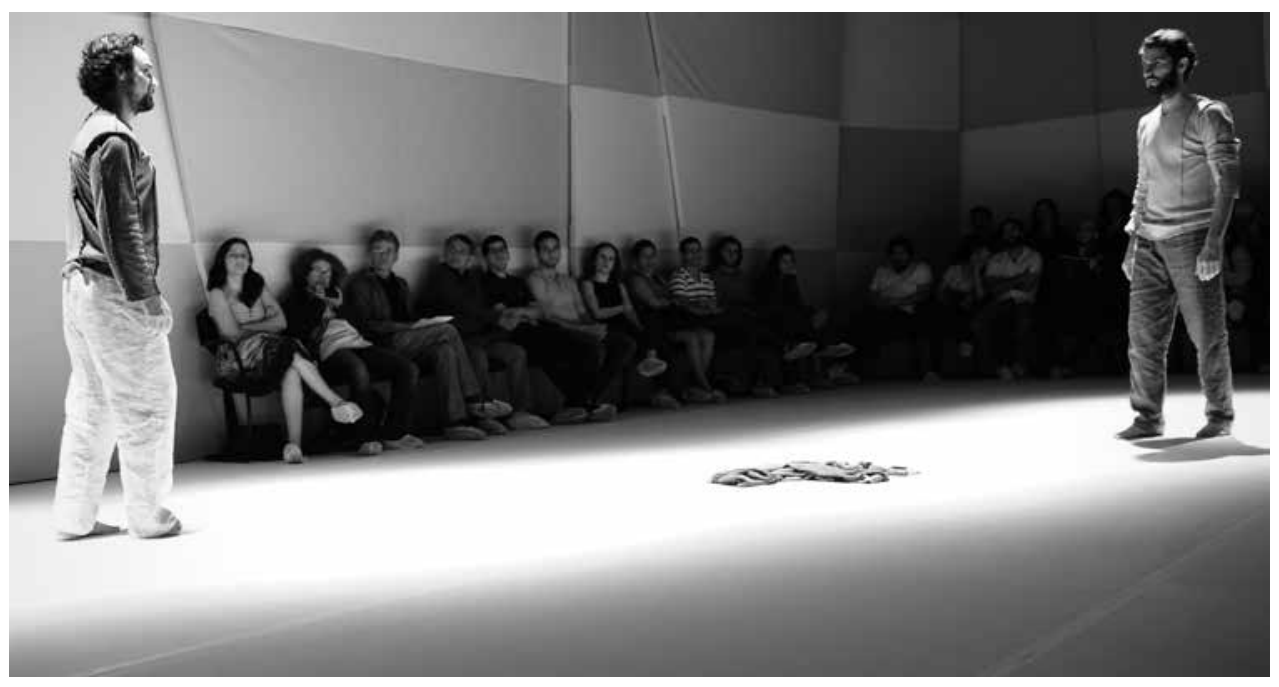

NA SOLIDÃO DOS CAMPOS DE ALGODÃO, DE BERNARD-MARIE KOLTÈS, ENC. ANTONIO GUEDES, COMPANHIA DO ATOR NU, 2012 (TAY LOPEZ E EDJALMA FREITAS), [F] JORGE CLESIO

o pensamento, mas a garantia de que este, pela palavra, pode ser lançado e voar, livremente. E Artaud tinha total consciência da necessidade de recuperar essa estranheza da linguagem, de recuperar essa tragicidade.

Ou somos capazes de voltar por meios modernos e atuais a essa ideia superior de poesia e de poesia pelo teatro que está por trás dos Mitos narrados pelos grandes trágicos antigos [...] ou, então, nada nos resta senão nos entregarmos imediatamente e sem reação, reconhecendo que só servimos para a desordem, a fome, o sangue, a guerra e as epidemias. (Artaud, 1983: 73)

Artaud desejava retomar uma ideia, segundo ele «superior», contida na tragédia grega. Não apenas buscar repeti-la, mas retomá-la «por meios modernos», ou seja, sob uma perspectiva atual. Porque ele via, na tragédia, o princípio da crueldade, tão caro ao seu projeto teatral. Ele via na tragédia uma função social voltada à revelação dos desejos mais primitivos. Via o homem ser devorado por sua palavra, via uma certa ideia de poesia que estaria por trás do relato dos mitos e de sua relação com o tempo presente. Percebia um certo uso da linguagem bem diferente daquele a que estamos habituados, mas que precisaríamos redescobrir e não apenas «desvendar a fórmula» e repetir. Artaud queria retomar algo que havia se perdido na tragédia ao longo do tempo e que teria sido enterrado decididamente quando os teatrólogos do século XVII, ao revisitarem a Antiguidade 
e interpretarem a Poética de Aristóteles, passaram a considerar o teatro como sinônimo de texto. Considerava a mera fruição de uma história uma traição ao princípio daquele acontecimento cênico grego no qual o destino do homem se punha em questão pela linguagem. Mas não uma linguagem domesticada, subserviente; Artaud se referia a uma linguagem cruel, surpreendente, trágica que, à revelia do homem que pronunciava as palavras, voltava-se contra ele obrigando-o a reconhecer sua arrogância, sua fragilidade e a impossibilidade de conhecer-se.

Artaud não realizou seu projeto. Entretanto, na tentativa de descrever sua necessidade de expressão, na busca pelo caminho que tornasse o acontecimento teatral uma experiência real, mesmo sem consegui-lo plenamente, ele possibilitou que seus contemporâneos inquietos e seus sucessores inconformados com o aspecto seguro da linguagem, uma linguagem entendida como um domínio do homem, pudessem buscar a retomada da compreensão da linguagem como uma experiência e não como um meio.

Em um ensaio sobre van Gogh, Artaud fala da sua pintura como um espaço de criação e não como cópia do mundo. E exalta a concretude de suas imagens, que, em vez de buscarem a descrição visual de temas, edificam realidades picturais, invertendo o modelo e instituindo a ideia de pintura como uma realidade à qual deveríamos retornar para entender a natureza:

\footnotetext{
Exclusivamente pintor, van Gogh, e nada mais, nada de filosofia, nada de mística, nada de rito, nada de psicurgia nem de liturgia, nada de história, nada de literatura nem de poesia, esses girassóis de ouro bronzeados são pintados; estão pintados como girassóis e nada mais, mas para entender agora um girassol natural, é obrigatório passar por van Gogh, assim como para entender uma tempestade natural, um céu tempestuoso, uma planície da natureza,
} de agora em diante é impossível não voltar a van Gogh. (Idem: 142)

É desse jogo que trata a concepção de linguagem descolada de uma função instrumental. De uma expressão que não descreve um modelo, é realidade. Artaud, seus contemporâneos e todos os criadores depois deles puderam dialogar com o classicismo e com o simbolismo a partir de uma confortabilíssima distância. Um espaço preenchido de experiências fundamentais no que diz respeito à questão da narrativa poética, 
da tensão entre realidade e ficção e da retomada de uma linguagem entendida como potência. Uma palavra compreendida não mais como uma ferramenta, mas como matéria. Como os girassóis de van Gogh.

UM DEBATE CONTEMPORÂNEO

No debate sobre as formas narrativas na contemporaneidade, alguns estudiosos consideram que há, na produção atual, um diálogo com a tradição teatral e que, portanto, a dramaturgia não estabeleceu uma ruptura com a forma tradicional. Pelo contrário, ela é hoje, um híbrido no qual a forma dramática dialoga com a forma narrativa (ou épica). Sarrazac escreve que «a forma dramática moderna e contemporânea é um terreno extremamente movediço de mutações e de experimentações permanentes» (2011: 46). Há outra corrente que considera que a forma épica resultou numa superação da forma dramática, criando uma ruptura com a tradição dramatúrgica. Entretanto, os defensores de ambas as posições concordam que a reflexão de Peter Szondi sobre a dramaturgia sinaliza de forma clara que, no final do século XIX, o drama clássico, que encontra sua plenitude com o naturalismo, entra em crise.

É sobre essa crise que me debruço ao pensar sobre a palavra no teatro contemporâneo. Meu objetivo é confrontar a linguagem com o que se convencionou afirmar que seria a sua finalidade última: a comunicação. Se a forma dramática procura descrever a ação por meio do diálogo e a forma épica descreve a ação de forma narrativa, há em ambas as formas o objetivo de comunicar alguma coisa. Conta-se uma história, descreve-se uma ideia utilizando a linguagem - sob diferentes formas. Mas, ao questionar o princípio da linguagem entendida como instrumento da comunicação, uma outra janela se abre para a reflexão sobre a palavra no teatro. Considero que está aí o fundamento da ruptura empreendida pelo simbolismo. Porque não se trata de trabalhar a linguagem como uma ferramenta de difusão de pensamentos, como meio, como veículo de informações. Trata-se de buscar, a partir da linguagem, instaurar, na relação entre a cena e o público, um espaço real que não se preocupa com uma lógica externa àquela experiência; trata-se de criar um espaço com uma lógica própria e que, portanto, não tenha preocupações com a ambiguidade ou com a convivência entre dimensões compreendidas como opostas entre si, como o real e o ficcional, o passado e o presente, a vida e a morte. Portanto, não há interesse em pensar a linguagem a partir de 


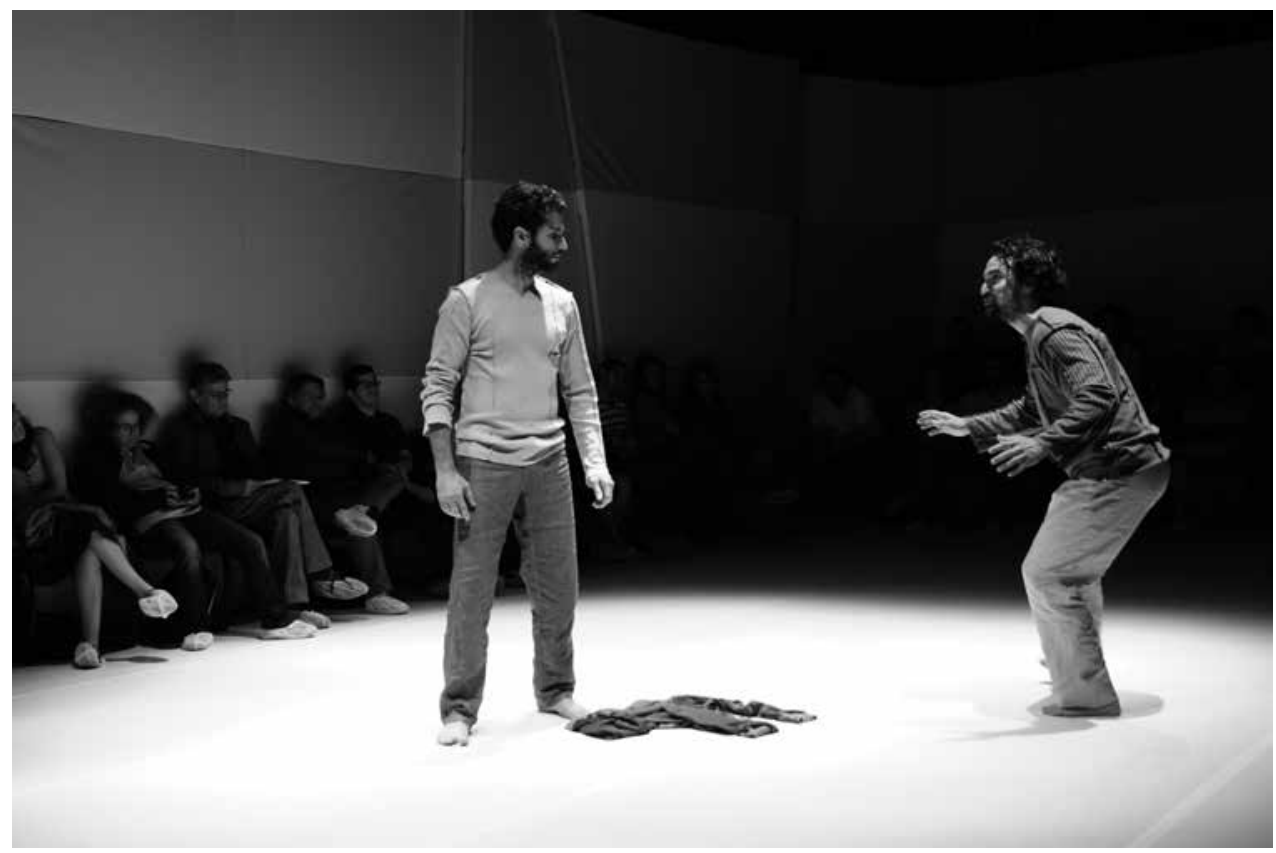

NA SOLIDÃO DOS CAMPOS DE ALGODÃO, DE BERNARD-MARIE KOLTĖS, ENC. ANTONIO GUEDES, COMPANHIA DO ATOR NU, 2012 (EDJALMA FREITAS E TAY LOPEZ), [F] JORGE CLESIO

uma perspectiva formal - dramática ou épica - porque esse debate não chega a tocar no fundo da questão sobre a instrumentalização da linguagem. $O$ foco está na reflexão sobre a potência poética ${ }^{1}$ da palavra.

Procurando fazer a leitura da escrita contemporânea a partir de uma perspectiva da linguagem que passe ao largo do debate sobre as formas narrativas, retomo trabalhos que realizei recentemente buscando explicitar o conceito que levou à definição de suas estruturas cênicas. Quando encenei Primeiro Amor, de Beckett, e Na Solidão dos Campos de Algodão, de Koltès, dois textos que sinalizam um rompimento com a narrativa tradicional, vi a oportunidade de abordar a palavra compreendida como protagonista do espetáculo. Isso significou empreender uma leitura desses textos recusando uma interpretação psicológica para as personagens, encarando as palavras ditas não como o resultado de uma motivação interior de «certos indivíduos», mas exatamente como o que são: palavras que integram um discurso. Sem subtexto, porque o sentido não está dentro do texto. Está no exterior, na superfície.

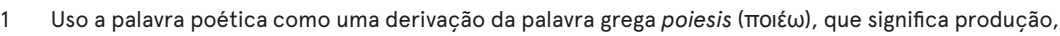
criação, não necessariamente ligada à criação artística. 
A personagem, nessa perspectiva, é a própria fala. $\mathrm{O}$ ator não interpreta: é a voz que lança as palavras na direção da plateia. Não há um «alguém» que fala. Há a fala.

O DISCURSO

Bernard-Marie Koltès construiu seu texto com 36 falas, 18 para cada personagem. A peça tem uma estrutura que lembra um debate formal: dois opositores se encontram, um dealer, personagem cuja descrição constitui a única didascália da peça, e um cliente. As primeiras falas são discursos retóricos, construídos à maneira clássica, que buscam o convencimento. Pretendem ser articulações de uma verdade inquestionável que será rebatida pelo outro em uma réplica que constituirá um novo discurso defendendo o contrário do primeiro. Uma verdadeira disputa sofística na qual o que importa é a persuasão; uma luta renhida com palavras organizadas com o objetivo de vencer o outro a partir de uma construção lógica. Na medida em que o embate avança, as falas vão abandonando este caráter retórico e se tornando cada vez mais agressivas e mais próximas de um diálogo (ou um embate físico) convencional.

Se uma visada superficial poderia sugerir uma construção maniqueísta do conflito no qual as personagens funcionariam como lados opostos de uma questão, ao longo da peça fica nítido que ambos fazem parte de uma unidade representada pelo jogo - um jogo constituído pela linguagem.

O mote da situação é o comércio, mas a questão é: o que comerciam? A maior parte das encenações desse texto optou por situar as personagens num beco escuro ou num galpão abandonado, enfim, num lugar propício às negociações proibidas. Tráfico de drogas? Prostituição? As falas são ambíguas e resvalam tanto nos desejos como nos vícios.

A tentação, para o encenador, é sempre a de revelar quem seriam esses homens, é ilustrar o espaço de forma a esclarecer as personagens e, consequentemente, a situação. É uma tentação tornar claro o que é obscuro, «resolver» aquiloque parece enigmático, preencher as lacunas. Entretanto, esse seria o caminho que tornaria os diálogos - que, na verdade, são justamente o que nos atrai neste texto-falas plausíveis de personagens fictícias. Ora, é justamente na ambiguidade que repousa a proposta de Koltès.

Minha encenação situava as personagens em um lugar limpo, quase branco. Porque as personagens não são indivíduos por princípio, visto que seus nomes - Dealer e Cliente - e a maneira como se dá o embate 
entre eles faz que se assemelhem a peças de um jogo. Seria um equívoco considerar essas personagens sem nome como indivíduos. São ideias em tensão, são forças que experimentam sua potência, são instrumentos que têm como objetivo mostrar que a verdade é uma construção retórica. Portanto, se o mundo no qual estão imersas existe porque eles falam, estamos diante de um mundo retórico. Um mundo que só se constitui pelo discurso, pelo jogo no qual a tese e a antítese, longe de significarem lados que se opõem, constituem uma unidade indissociável na construção de um mundo. $O$ espaço branco da minha encenação, qual papel branco à espera da escrita, funcionava como uma tela sobre a qual o sentido da cena seria impresso.

O espetáculo repousava fundamentalmente sobre o texto e sobre o trabalho dos atores. Um preciso exercício de elocução se fez necessário, especialmente por causa da construção retórica das falas. Frases de vinte, trinta linhas, muitas vezes com aposto dentro de aposto. Os corpos dos atores estavam em cena preparados para um combate, prontos para se esquivar ou efetuar um golpe a qualquer momento. Mas não havia contato: as palavras eram lançadas e os golpes estavam na argumentação que tentava derrubar o discurso do adversário. O espetáculo, dividido em rounds, era pontuado por instantes em que cada ator retornava ao seu banco no canto do ringue onde descansavam, concentrados, enquanto um vídeo projetava suas imagens no chão branco do cenário, situando-os em locações que poderíamos imaginar como ambientes propícios a um encontro como aquele: um galpão abandonado, uma rua de periferia, um elevador que os levaria a algum pavimento suspeito ou até mesmo num fundo branco saturado situando-os exatamente onde estavam. Em seguida, retomavam o combate.

O público, muito próximo, se punha à parte, mas dentro do ringue, podendo dimensionar a si próprios naquele embate que substituía violentos golpes físicos por argumentações violentamente lógicas.

Ao final, depois de intensa troca de argumentos na qual as palavras eram lançadas de um lado para outro sem uma pausa sequer, o cliente lança, finalmente, uma pergunta: «Então, qual é a arma?» Um silêncio. Nesse momento percebemos que não fomos levados a lugar nenhum. Justamente, a conclusão do diálogo, o sentido daquele combate é a inexistência de armas... pois, se parecia haver uma luta, no fim percebemos que não há diferenças entre Dealer e Cliente. Cada um representa uma ideia que é concretizada em cena a partir de diferentes retóricas, entretanto, aquelas falas, construídas como discursos clássicos, 
PRIMEIRO

AMOR, DE

SAMUEL

BECKETT,

ENC. ANTONIO

GUEDES,

COMPANHIA

TEATRAL DO

MOVIMENTO,

2012 (ANA

KFOURI),

[F] DALTON

VALÉRIO

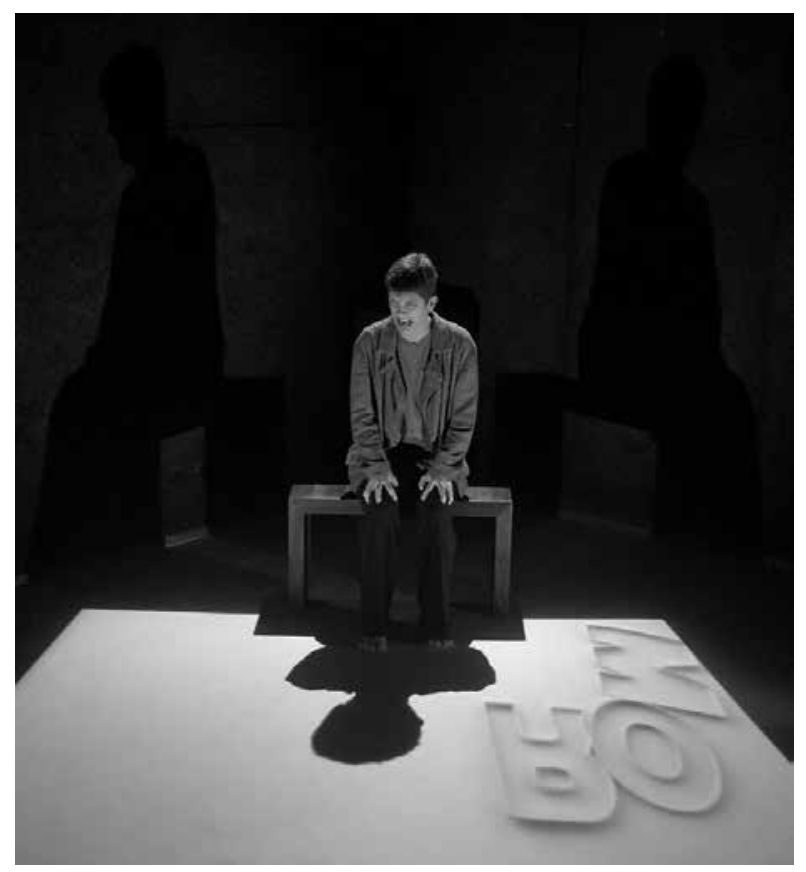

proferidas como se fossem verdades indiscutíveis, são, enfim, circunstanciais. Koltès esvazia o discurso utilizando-se da profusão de palavras. No fim, no fundo, não sobra nada. Não há nada.

Podemos dizer que, em Na Solidão dos Campos de Algodão, o discurso é o protagonista.

Novela escrita em 1945, em primeira pessoa, trabalha uma fábula, uma história de amor que apresenta uma personagem absolutamente marginal: um mendigo que, ao se apaixonar por uma prostituta, fica incomodado com esse sentimento, pois a paz que a solidão sempre lhe proporcionou chega ao fim. Quando ela não está, a angústia por sua ausência desvia sua atenção do prazer do isolamento; quando ela aparece, ele se sente livre da angústia produzida pelo amor, mas se vê na desagradável obrigação de se relacionar com ela. A desconstrução romântica fica óbvia quando ele se pega, distraidamente, escrevendo «Lulu», o nome dela, em esterco velho e seco.

Tendo decidido morar com ela, precisa conviver com os ganidos emitidos pelos clientes que ela recebe em casa. Quando ela engravida, 
a situação se torna intolerável. O mito materno, a expectativa pelo bebê, seus movimentos na barriga, a esperança pelo futuro, tudo é motivo para uma felicidade verbalizada e isso é infinitamente desagradável. Mas, quando a criança nasce, os gritos do parto e o choro do bebê... então já não é mais possível: ele a abandona e escolhe a solidão, que passa agora a estar preenchida pelo horrível incômodo do sentimento do amor. E vive, para sempre inadequado para a vida. Essa novela de Beckett, ainda longe das narrativas curtas e fragmentadas que caracterizam sua obra a partir da década de 1970, desconstrói completamente a ideia de uma personagem com sentimentos nobres, apresentando uma figura que, feliz ao não sentir nada, percebe o amor como um sentimento torturante.

A encenação de Primeiro Amor foi um processo de construção negativo: em vez de inserirmos elementos na cena, excluímos. Até chegarmos ao mínimo: a atriz, sentada num banco, num canto da sala, falando, falando. O movimento de cena se limitou aos gestos dos braços e à lenta variação da iluminação que projetava a sombra da atriz nas paredes, como se multiplicássemos seus gestos. À frente dela, no chão, um vídeo construído a partir de letras que não chegavam a formar palavras era projetado. Como um moto contínuo na cabeça da personagem, sem discurso, sem sentido. Do relato da atriz, depreende-se que o amor, na perspectiva do desejo de solidão, é puro sofrimento.

A solidão é um mote que acompanha a obra de Beckett, uma solidão preenchida por histórias, cuja veracidade não é importante. Ele constrói histórias para que personagens existam, mas não que elas tenham importância... são apenas nomes ou rostos. O que importa é que sua existência se baseia na narrativa. Não no conteúdo do que se fala, mas na própria fala. Ao ouvirmos uma voz, temos a impressão de que alguém fala. Mas não podemos afirmar que há alguém... mas há a fala, portanto, talvez haja alguém.

Maurice Blanchot, em «Agora onde? Agora quem?» (1984: 221-7), nos fala sobre a dissolução da personagem ao refletir sobre a trilogia Molloy, Malone Morre e O Inominável, romances escritos em primeira pessoa. E a pergunta que ele se faz é: «Quem fala nos livros de Samuel Beckett?» No primeiro romance, Molloy é um homem que, mesmo desestruturado, desenvolve ainda uma história e revela, em sua fala, referências do seu passado de maneira a identificarmos, ali, traços de individualidade. Já Malone é um moribundo sobre uma cama. Não se desloca mais, e suas histórias são invenções que nunca aconteceram. Portanto, não sabemos nada sobre ele. Há um nome e um rosto, mas 
não há qualquer sinal de identificação nas suas falas. No terceiro e último... bem, o título já nos sugere: é um $e u$ sem nome. Não há sequer um rosto. Resta apenas a possibilidade de falar.

O sujeito em Beckett é sempre menos do que sua fala. Suas personagens são destroços humanos - quando não são partes de corpos - que dependem da narrativa para existir. Não são homens idealizados com um passado que justifique o presente; são figuras precárias, inúteis. Também no amor, suas personagens são incompetentes. Tudo o que elas querem é mergulhar na sua condição última: a solidão. Condição que só pode ser superada pela possibilidade de, talvez, haver uma história na qual eles, talvez, se encontrem. Talvez.

Entretanto, como fala a personagem d'O Inominável:

[...] é preciso continuar, não posso continuar, é preciso continuar, então vou continuar, é preciso dizer palavras, enquanto houver, é preciso dizê-las, até que elas me encontrem, até que elas me digam, estranha pena, estranho pecado, é preciso continuar, talvez já tenha sido feito, talvez já tenham me dito, talvez já tenham me levado até o limiar da minha história, diante da porta que se abre para a minha história, isso me surpreenderia, se ela se abrir, vai ser eu, vai ser o silêncio, ali onde estou, não sei, não saberei nunca, no silêncio não se sabe, é preciso continuar, não posso continuar, vou continuar. (Beckett, 2002: 189)

Beckett poderia continuar o romance infinitamente... porque sua narrativa não tem lugar para chegar. Mas ele põe um ponto final obrigando o leitor a fechar o livro. Com Beckett, a linguagem não tem mais nenhum objetivo, nenhum fim. Ele fala sobre a fala.

Diz-se que o amor preenche o corpo, antes vazio. Mas o Primeiro Amor de Beckett não tem futuro... se houver futuro, é vazio. Um vazio povoado de palavras.

Não há sujeito... ou melhor, a fala é o protagonista.

VALÈRE NOVARINA - UMA PRIMEIRA EXPERIÊNCIA

A atmosfera predominante, tanto em Beckett quanto em Koltès, era carregada de angústia e falta de sentido. Entretanto, ao experimentar a encenação de um texto de Novarina, no qual eu entendia que a palavra também era protagonista, chamou-me a atenção uma novidade que 
considero particularmente fundamental nessa visada sobre o diálogo com o teatro tradicional: o sorriso, o gozo, o prazer pelo jogo. Mas essa não é uma conclusão evidente. Dada a particularidade da narrativa, é preciso contextualizar a estranheza da fala novariana.

Em meu primeiro contato com Novarina, a impressão foi que sua narrativa não me trazia nenhuma novidade. Nada que eu já não conhecesse a partir das falas angustiadas de Artaud ou dos elípticos ensaios de Blanchot. Claro que havia em Novarina inteligência e poesia, mas eu não via nada além de uma espécie de afogamento contemporâneo pelo excesso de sentidos e de conteúdos.

Convidado para dirigir O Animal do Tempo (Novarina, 2007: 7-31), depois de ler e reler o texto, não sabia dizer qual era o núcleo da narrativa. Só ao ouvir uma primeira leitura com a atriz percebi que, no lugar de um fio narrativo - expressão impossível de utilizar em relação a esse texto-, encontrava-se uma potência narrativa que mais se assemelhava a um mergulho em um labirinto.

Nesse primeiro contato real com a narrativa de Novarina, percebi que o poder embriagador do texto estava em sua elocução. Eu acabava de experimentar as palavras. Não o significado, mas sua potência de produzir sentidos a partir da forma, da sonoridade, do ritmo. A chave do prazer deste texto não estava numa compreensão intelectual.

Uma das coisas que sempre me interessaram na cena desejada por Artaud era a exigência de precisão e o rigor da ordenação dos sons, imagens e palavras que deveriam ser definidas no espetáculo imaginário do teatro da crueldade. Era a busca por uma dimensão onírica que prescindiria do relato ou da organização lógica dos acontecimentos. Não se tratava de «suprimir o discurso articulado, mas de dar às palavras mais ou menos a importância que elas têm nos sonhos» (Artaud, 1984: 120).

Artaud foi buscar essa sonoridade em línguas primitivas, em sons guturais, na expectativa por uma palavra encantatória que havia perdido sua potência ao longo da história do Ocidente. Ele estava atrás de uma linguagem para a cena que recuperasse, para o acontecimento teatral, uma experiência originária a partir da configuração e da perfeita ligação entre palavras, sonoridades e imagens simbólicas. Para Artaud, a experiência teatral não estava na fábula, mas nas imagens e lembranças que a experiência com a linguagem poderia evocar.

Essa busca por uma dimensão da linguagem que funda o sentido não na compreensão lógica, mas na experiência teatral - ou seja, na ação simultânea do sentido das palavras, da sonoridade da fala e a presença 
do ator - parecia ter se concretizado ao fim da primeira leitura em voz alta d'O Animal do Tempo. Pude afirmar que via sentido naquele texto, mas não podia, a partir daí, constituir uma história única. Era uma oportunidade de trabalhar uma narrativa cujo sentido se revelava ao ser soprada, ao ser lançada no espaço. Como uma partitura musical, o texto, ao ser «entoado», produzia e tocava os sentidos. Como as sinfonias.

NOVARINA E A LÍNGUA DESCONHECIDA

Ouvir O Animal do Tempo pela primeira vez me levou a um lugar que eu não conhecia. Os neologismos, associados à construção de frases que pareciam ser feitas por alguém que não domina a língua que está falando, davam a impressão de que a atriz que falava era um sujeito inadequado, que fala sem perceber. Isso me fez lembrar de um trecho d'O Teatro da Morte, no qual Tadeusz Kantor procura relatar a sensação causada pelo surgimento do primeiro ator:

Um homem havia se erguido diante daqueles que ficaram do lado de cá, exatamente igual a cada um deles e, no entanto, (por uma «operação» misteriosa e admirável) infinitamente distante, terrivelmente estrangeiro, como que habitado pela morte, separado deles por uma barreira não menos apavorante e inconcebível por ser invisível, como o verdadeiro sentido da honra, que só pode ser revelado pelo sonho.

Assim, à luz cegante de um raio, eles perceberam de repente a Imagem do homem, gritante, tragicamente clownesca, como se a vissem pela primeira vez, como se acabassem de ver a si próprios. Essa foi, seguramente, uma percepção que se poderia qualificar de metafísica. (Kantor, 2008: 202)

O sentimento de estranheza ao ver a si próprios como se fosse a primeira vez é uma experiência originária. É o reconhecimento, a identificação com um outro que sou eu. A esse encontro, Beckett chama «o espanto». E ouvir o texto de Novarina me fez pensar sobre essa reação. O espanto como um reconhecimento e, ao mesmo tempo, como algo incompreensível.

Como Kantor, Novarina busca produzir, em sua narrativa, justamente essa distância, esse afastamento que faz que vejamos a nós próprios, como se pudéssemos ver-nos fora de nós: 


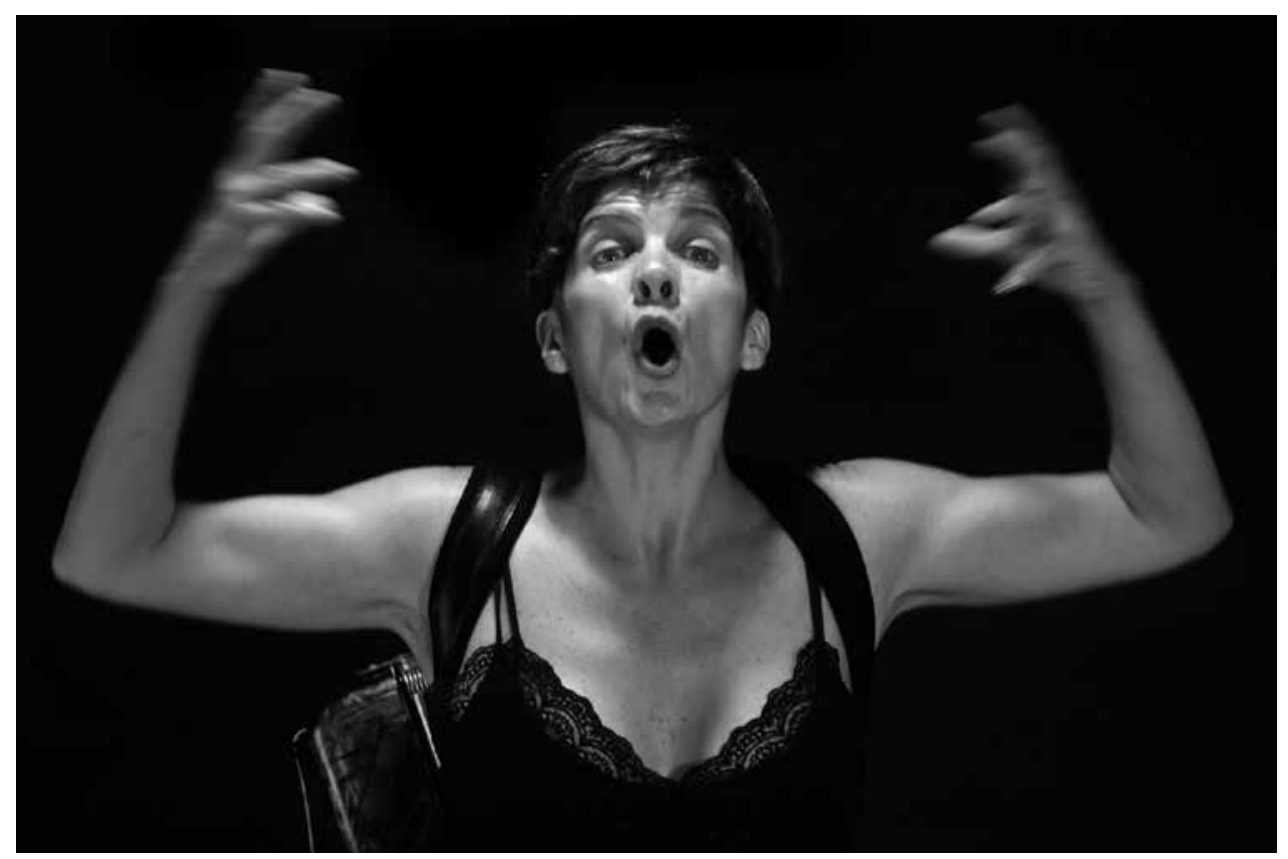

O ANIMAL DO TEMPO, DE VALÈRE NOVARINA, ENC. ANTONIO GUEDES, COMPANHIA TEATRAL DO MOVIMENTO, 2007 (ANA KFOURI), [F] DALTON VALÉRIO

À l'âge de dix-huit ans, j'ai eu une sorte de bizarre illumination en feuilletant dans tous les sens une grosse thèse très mystérieuse, écrit sur Un coup de dés de Mallarmé. [...] je me suis cru placé à la croisée du drame du corps et de la parole. Au croisement des contraires: la page plate du livre et la page charnelle du théâtre, en volume. Dans la croix des contraires, une unité incompréhensible était à saisir. Ce que je cherche aujourd'hui du côté du corps vide de l'acteur, c'est I'homme hors de lui. (Novarina, 2002: 166)

O drama do cruzamento dos opostos: o corpo e a palavra; a página plana do livro e a espacialização do teatro. Entre a página e o palco, no cruzamento, a palavra. A palavra que se encontra nessa encruzilhada não pode ser objetiva, precisa, porque ela é ambígua por princípio, ela pertence a dois lugares distintos, a duas dimensões. Neste ponto de encontro, há conflito, há nebulosidade ou excesso de luz; há confusão. Esse é o lugar do ator, aquele que vai soprar e espacializar a palavra escrita. E é o ator quem irá encarnar o homem fora de si, o corpo que se revela outro «exatamente igual a cada um deles e, no entanto, [...] infinitamente 
distante, terrivelmente estrangeiro, como que habitado pela morte» (Kantor, 2008: 202).

No encontro da superfície plana do papel com o volume do espaço, há estranhamento. Nesse espanto beckettiano, as palavras se tornam também estranhas e, portanto, visíveis. Perdem a naturalidade e saltam aos olhos, mostram-se independentes do seu significado, revelam-se como gesto e não como a descrição de uma ação. E é essa palavra estranha, desconhecida, que revela o homem fora de si a falar uma língua incompreensível.

Em Une langue inconnue (Novarina, 2012), Novarina conta que, em criança, sua mãe tocava ao piano e cantava para ele e para seu irmão. Quando o pai não estava em casa, ela encerrava a sessão com a canção que um namorado húngaro tinha composto para ela há muito tempo. Sua mãe não sabia húngaro, não percebia nada do que cantava, mas punha uma tal emoção nessa canção que tornava esse o momento mais intenso das sessões musicais. Novarina chamou essa língua de «língua materna incompreensível». E afirma que as línguas são também algo que não se compreende. Há qualquer coisa escondida na língua que nos revela ou nos faz lembrar da infância ou de alguém que já fomos.

É preciso também se espantar com sua própria língua, se surpreender pelo fato de sermos animais que falam. A gente vai ao teatro para se surpreender vendo animais falando de novo, se espantar de novo com a palavra. Mas é verdade que passei talvez mais tempo ouvindo música do que lendo ou lendo tratados de musicologia sem entender nada, e comprando partituras sem saber lê-las. Da mesma forma, tenho bíblias em hebraico. E assim livros impenetráveis agem sobre nós. (Novarina, 2011: 20)

NOVARINA E A PERDA DE SI: A RENÚNCIA

Há uma beleza e uma coragem na narrativa de Novarina: ele abraça a tarefa de produzir sentido, mas sem ter domínio, sem escolher o que será percebido. Ele lança a palavra sem mirar um alvo. Se o discurso tradicional, aquele que tem suas raízes no projeto renascentista deve eliminar ruídos para tornar preciso o objetivo, restringindo a possibilidade de percepção do sentido, a fala de Novarina, ao contrário, absorve os ruídos, integra sonoridades, agrupa e reinventa palavras, abre espaço, não o delimita. A palavra é lançada para que o espectador a articule: 
é uma janela que se abre para uma paisagem cujo ponto de fuga será definido pelo ouvinte. Nesse jogo, Novarina não diz. Ele se apaga para deixar reverberar a linguagem enquanto potência; renuncia «a qualquer ideia de expressão, de troca, comunicação, mestria, aprendizado. Ele teria querido desaprender, não falar mais uma língua que dita, que nos foi ditada» (Novarina, 2011: 19-20). Ele rejeita aquela língua que descreve o que se pensa para reencontrar uma língua muda, uma língua negativa. Sua escrita está fora da estruturação do discurso que tem seu objetivo na comunicação; ele abre mão do conteúdo, renuncia a ter uma mensagem a ser transmitida. Porque para Novarina, «a língua não é teu instrumento, teu utensílio, mas tua matéria, a própria matéria da qual você é feito [...]. Pois você é feito de palavras. Não de nervos e de sangue. Você foi feito pela língua, com a língua» (ibidem: 39-40).

Segundo Levinas, «a essência da linguagem é a relação com Outrem» (Levinas, 2014: 202). Ou seja: o jogo só se torna possível num gesto de generosidade. Para falar e para ouvir, o jogo está numa relação com o outro, onde não cabem nem imposição de individualidades, nem papéis sociais ou hierárquicos. Nada mais político!

Beckett já trabalhava um sujeito desfeito, cujo conceito está acabado, falido. Mas, um discurso que aponta para a ausência, para a falta de algo ou alguém que talvez já tenha estado ali. Novarina propõe um homem fora de si, o sujeito esvaziado, «sem ninguém dentro» (Novarina, 2011: 31) que fala, que lança a palavra no espaço. Não para dizer algo, mas para afirmar que a fala está ali. Se a fala em Beckett vem carregada de uma atmosfera vazia angustiante, em Novarina, a fala é a feliz constatação de que o sentido é algo construído pelo outro e não há melhor brinquedo para preencher o vazio do que construir sentidos, muitos, mas sem que eles se enrijeçam e adquiram o aspecto de uma fala verdadeira.

Não há novidade na proposta de Novarina. Craig, Artaud e mais tarde Grotowski buscaram esse ator esvaziado, destituído de um «sujeito social» construído ao longo de sua vida, para se apresentar como uma ligação entre a palavra e o público. Mas, sem dúvida, sua proposta é de uma generosidade quase impossível, na medida em que ele abre mão de ser dono do discurso. É uma fala «sem ninguém dentro»².

2 No original, sans personne dedans. Segundo nota da tradutora Ângela Leite Lopes, «personne pode significar tanto pessoa, alguém, quanto ninguém». 
Quando a perda deixa de ter um sentido negativo, quando passa a se ligar ao sentido de liberdade, compreender a linguagem como instrumento de comunicação torna-se uma redução extrema. Porque, da mesma forma que fomos feitos pela língua, com a língua, o mundo também foi feito pela língua. E é refeito a cada nova elocução. A realidade está na perspectiva a partir da qual percebemos o mundo. Nesse sentido, pensar o mundo e inventar o mundo são construções semelhantes.

Como os girassóis de van Gogh.

\section{REFERÊNCIAS BIBLIOGRÁFICAS}

ARTAUD, Antonin (1977), Nouveaux écrits de Rodez, Paris, Éditions Gallimard.

-- (1983), «Acabar com as obra-primas», Escritos de Antonin Artaud, trad. Cláudio Willer, Rio Grande do Sul, L\&PM Editores.

-- (1984), O Teatro e Seu Duplo, trad. Teixeira Coelho, São Paulo, Max Limonad.

BECKET T, Samuel (2002), O Inominável, trad. Maria Jorge Vilar de Figueiredo, Lisboa, Assírio \& Alvim. BLANCHOT, Maurice (1984), O Livro por Vir, trad. Maria Regina Louro, Lisboa, Relógio D’Água Editores. KAN TOR, Tadeusz (2008), O Teatro da Morte, trad. Jacó Guinsburg et al., São Paulo, Perspectiva. LEVinas, Emmanuel (2014), Totalidade e Infinito, trad. José Pinto Ribeiro, Lisboa, Edições 70.

NOVARINA, Valère (2002), «L'homme hors de lui», Europe n. ${ }^{\circ}$ 880-881, Paris, Europe, agosto-setembro, pp. 162-75.

-- (2007), Discurso aos Animais, trad. Ângela Leite Lopes, Rio de Janeiro, 7 Letras.

-- (2011), Teatro dos Ouvidos, trad. Ângela Leite Lopes, Rio de Janeiro, 7 Letras.

-- (2012), Une Langue Inconnue, Carouge-Genève, Éditions Zoé.

SARRAZAC, Jean-Pierre (2011), O Outro Diálogo, trad. Luís Varela, Lisboa, Editora Licorne.

\section{ANTONIO GUEDES}

Antonio Guedes é professor na Escola de Belas-Artes da Universidade Federal do Rio de Janeiro - Brasil e doutorando do curso de Artes Performativas e da Imagem em Movimento da Universidade de Lisboa. É encenador e diretor artístico da companhia carioca Teatro do Pequeno Gesto. 